\title{
In Situ Preservation of Underwater Cultural Heritage as an International Legal Principle
}

\author{
Mariano J. Aznar \\ Professor of Public International Law, Universitat Jaume I, Spain. maznar@uji.es \\ ORCID: 0000-0003-4579-7730
}

This is a pre-print of an article published in Journal of Maritime Archaeology. The final authenticated version is available online at DOI: $10.1007 / \mathrm{s} 11457-018-9192-4$

Keywords: in situ preservation, international law, underwater cultural heritage, 2001 UNESCO Convention

\begin{abstract}
In situ preservation is not necessarily the best underwater archaeological solution, nor is it legally required in all circumstances. Rather, it is the first and, perhaps, the most technically desirable option, when archaeological, legal, and political circumstances - in that order - so advise. Otherwise, the removal of the historical object or objects found under the sea and their conservation outside the marine environment is another plausible option, provided the archaeological standards accepted by the international scientific community are met.

This paper aims to clarify the legal contours of this rule, as codified by the UNESCO Convention on the Protection of the Underwater Cultural Heritage. To this end, it proposes the following basic hypothesis: in situ preservation, as a current legal principle in underwater archaeological activities, is the first option for the protection of that heritage; because it is an option, this preservation may take a different form depending on the circumstances; nothing legally prevents the removal of remains from the seabed, provided it is done properly and they are appropriately preserved; and, finally, if necessary, this should be done as soon as possible, given the circumstances.
\end{abstract}

\section{Acknowledgments}

The author would like to thank Filipe Castro, Dolores Elkin, Thijs Maarleveld, Manuel Martín Bueno and Xavier Nieto for their most valuable comments on an earlier draft of this article. However, the views expressed herein are solely those of the author, as are any errors. All websites last visited 12 April 2018.

\section{Introduction}

Perhaps one of the biggest and most frequent mistakes made by those considering the protection of underwater cultural heritage for the first time (or, in some cases, those who do so with an agenda) is to believe that it must always, and in all cases, be protected in its original location. The in situ preservation of underwater cultural heritage is thus conceived of as a mandatory rule that brooks no exception, which is simply false or, at the very least, not entirely true.

Some view this supposedly absolute rule as an overzealous desire to protect, regardless of the specific needs of each underwater site. Others have accused it of serving as an excuse to do nothing in relation to underwater cultural heritage at all. Still others, even more self-interestedly, point to this rule as evidence of the inoperancy of the protection system commonly accepted in archaeology, setting it against people's right to learn about, when not visit, any archaeological site. Ultimately, this notion fuels the misunderstanding of those "who do not want any regulation to curtail their interests [and] will claim that archaeology is about finding things and therefore it would be ludicrous to say that things should be left in place" (Maarleveld et al. 2013, 20). The consequences arising from any of these charges are detrimental to the adequate protection and dissemination of underwater archaeological heritage. 
This paper will attempt to show that in situ preservation is not always the only archaeological solution, nor is it legally required in all circumstances. As we will see, in situ preservation is the first option, and perhaps the most technically desirable one, when the archaeological, legal, and political circumstances-in that order-so allow. Where circumstances advise otherwise, the removal of the historical object or objects located under the sea and their preservation outside the marine environment is another plausible option, provided the archaeological standards accepted by the international scientific community are met.

This paper aims to clarify the legal contours of this rule, as enshrined in the UNESCO Convention on the Protection of the Underwater Cultural Heritage (hereinafter, 2001 UNESCO Convention). ${ }^{1}$ To this end, it will present the following basic hypothesis: in situ preservation is the first option for the protection of underwater cultural heritage; because it is an option, this protection may take a different form depending on the circumstances; there is nothing legally preventing the removal of remains from the seabed, provided it is done properly and they are appropriately conserved; and, finally, this should be done as soon as possible, given the circumstances.

To develop this hypothesis, this paper will be structured as follows. First, it will examine the content and scope of the principle of in situ preservation and, in particular, its scientific affirmation with regard to underwater archaeology (infra 2); next, it will look at how this principle has been received and enshrined in law at the international and comparative level (infra 3); finally, it will conclude with an overall critical assessment of what has been done to date with regard to wrecks and the need to proceed to their proper protection.

\section{In situ preservation as an archaeological principle}

The principle of in situ preservation is a meta-legal concept in the sense that the law only imposes it indirectly, as it goes beyond the bounds of the strictly legal. As we will see, despite its widespread acceptance in the scientific community, it was some time before the concept was incorporated into the law. In short, it is a commonplace in archaeology that, to the extent possible, every site should be preserved in its original location in order to preserve its context. "Original location" is understood to mean the place where the object was used for the last time by the person or people associated with it, i.e., when it was in its "original" context. However, that "context" may have been altered over time: physical changes, caused by anything from changing ocean currents to the development of a hillside, may have displaced the object from its "original" context to a "new" one, which is nevertheless still relevant. The necessary preservation of the natural context surrounding the archaeological site thus makes in situ preservation even more challenging.

Although it was not so until fairly recently (Sease 1996), the principle of in situ preservation was confirmed as the first option in contemporary archaeology in the second half of the $20^{\text {th }}$ century. The turning point seems to have come in the wake of World War II, during the reconstruction of the long list of places laid to waste by the armed conflict. It was also influenced by the emergence of a "new archaeology," accompanied by new means and, especially, a new vision of the discipline and its techniques embraced by a whole new generation of archaeologists until the turn of the century (Rahtz 1974; Gianfrotta and Pomey 1981; Cleere 1984; Trotzig and Vahlne 1989; Thomas 1989; Hodges 1993; Carman et al. 1995; ICOMOS 1996) (in the French literature, see Les cahiers d'archéologie subaquatique from 1972). This was especially accepted with regard to "waterlogged" sites (Lillie and Smith 2009) and, in particular, underwater ones (Langley and Unger 1984; Vlad Borrelli 1995).

In the literature confirming in situ preservation as a first option, the vast majority of authors generically assert three closely intertwined ideas. First, as an option, in situ preservation is not absolute,

1 Convention on the Protection of the underwater Cultural Heritage, adopted November 2, 2001, entered into force January 2, 2009. 2562 UNTS 1 
i.e., it is not always and under all circumstances obligatory to preserve a site (and the objects and pieces removed from it) exactly how and where it was originally found. Second, and notwithstanding the foregoing, procedures that enable the preservation of the site's elements in their natural and historical context are preferable to more invasive techniques. This is because they also preserve their authenticity and facilitate the future scientific understanding thereof, both for the public in general and, in particular, for any future experts who might one day wish to undertake new studies at a site that has already been excavated. Third, regardless of the other two considerations, certain circumstances, both natural and manmade, ${ }^{2}$ may make it preferable to preserve the site and its objects in a different context. These circumstances (whether individually or jointly assessed) would include, among others, risks or hazards posed by the site, as well as the facilitation of better and more thorough scientific understanding or the social enhancement of the place and its historical elements. As has been noted elsewhere, "[a]uthenticity and context are therefore the principal arguments that heritage is best preserved in situ" (Maarleveld et al. 2013, 23). Likewise, "[m]inimum impact archaeology does not necessarily mean that systematic site testing or disturbance of any kind is always avoided. Minimum impact methodology should be a normal part of a total documentation strategy designed to produce cumulative data by exhausting non-invasive options before disturbing sub-surface sediments. Emphasis on remote sensing as an alternative to test excavation is one step in the cumulative hierarchical investigative approach to archaeological inquiry developed as part of minimum impact methodology" (Delgado 1997, 278).

In recent years, this principle, along with the conditions for its application and its exceptions, has been widely accepted in the literature, again both for archaeology in general, in times of peace (Burnouf 2012; Smith 2014) and armed conflict (O'Keefe et al. 2016), and for underwater archaeology in particular (Martín Bueno, 2003; Grenier et al. 2006; Manders 2012; Khakzad and Van Balen 2012; Maarleveld et al. 2013). Interestingly, these scholarly pronouncements have been accompanied by collective scientific discourses, the product of increased interrelation among researchers, as well as their organization into more or less stable international discussion forums. The quantity and quality of the threats to cultural heritage in general, and to underwater heritage in particular, have moreover allowed many of these groups (historians, archaeologists, curators, etc.) to find common cause in denouncing them through a series of documents, collectively adopted after much debate, published in the last few decades of the $20^{\text {th }}$ century and at the turn of the $21^{\text {st. }}$. The founding of scientific non-governmental organizations that have produced a number of documents and resolutions making concrete proposals played a decisive role in this regard. Of particular note, for the matter under discussion, are those discussed and adopted by the International Council of Monuments and Sites (ICOMOS) and the International Law Association (ILA). Not only have these scientific associations set the standard for offering protocols for archaeological action, their expertise has also been embraced by international intergovernmental organizations-especially, UNESCO and the Council of Europe (CoE) — which have adopted the recommendations of the scientific community on the matter as their own.

Thus, from very early on, UNESCO understood in situ preservation as a core principle of all archaeological activity. In its Recommendation on International Principles Applicable to Archaeological Excavations ${ }^{3}$ the organization noted that "[p]rior approval should be obtained from the competent authority for the removal of any monuments which ought to be preserved in situ" (paragraph 8). It further recommended that each Member State "consider maintaining untouched, partially or totally, a certain number of archaeological sites of different periods in order that their excavation may benefit from

2 At the risk of oversimplifying, it should be recalled that these adverse circumstances-whether naturally occurring or caused by human activity - can be physical/mechanical (climate change, landslides, changes in ocean currents, licit and illicit extractive activities, etc.), chemical/organic (action of living organisms, such as fungi or bacteria, changes due to chemical reactions with inorganic elements such as lime or salt, corrosion of metals due to aerobic changes, etc.), or, in many cases, a dangerous combination of both. They can moreover result in temporary or permanent alterations.

3 Recommendation on International Principles Applicable to Archaeological Excavations, December 5, 1956. 
improved techniques and more advanced archaeological knowledge. On each of the larger sites now being excavated, in so far as the nature of the land permits, well defined 'witness' areas might be left unexcavated in several places in order to allow for eventual verification of the stratigraphy and archaeological composition of the site"(paragraph 9).

A few years later, in its Recommendation concerning the Preservation of Cultural Property Endangered by Public or Private Works 4 it warned that "Member States should give due priority to measures required for the preservation in situ of cultural property endangered by public or private works in order to preserve historical associations and continuity. When overriding economic or social conditions require that cultural property be transferred, abandoned or destroyed, the salvage or rescue operations should always include careful study of the cultural property involved and the preparations of detailed records" (paragraph 9).

Meanwhile, in its Recommendation No $R$ (93) 9 on the protection of the architectural heritage against natural disasters, ${ }^{5}$ the $\mathrm{CoE}$ called for the preferential application of protection and preservation in situ, for example, in cases of protection of architectural heritage against natural disasters.

As noted, in addition to these two international organizations, two scientific associations-ICOMOS and the ILA-have had occasion to issue opinions on the principle of in situ preservation. The first time ICOMOS had the opportunity to express its scientific opinion on the matter was in its Charter for the Protection and Management of the Archaeological Heritage,${ }^{6}$ which notes that "[1]egislation should afford protection to the archaeological heritage that is appropriate to the needs, history, and traditions of each country and region, providing for in situ protection and research needs" (Article 3). In light of this, Article 6 of the Charter warns that "[t]he overall objective of archaeological heritage management should be the preservation of monuments and sites in situ, including proper long-term conservation and curation of all related records and collections etc. Any transfer of elements of the heritage to new locations represents a violation of the principle of preserving the heritage in its original context. This principle stresses the need for proper maintenance, conservation and management. It also asserts the principle that the archaeological heritage should not be exposed by excavation or left exposed after excavation if provision for its proper maintenance and management after excavation cannot be guaranteed."

Article 5 of the Charter further cautions, "It must be an overriding principle that the gathering of information about the archaeological heritage should not destroy any more archaeological evidence than is necessary for the protectional or scientific objectives of the investigation. Non-destructive techniques, aerial and ground survey, and sampling should therefore be encouraged wherever possible, in preference to total excavation."

A few years later, in its Charter on the Protection and Management of Underwater Cultural Heritage (Sofia Charter), ${ }^{7}$ ICOMOS stated that "[t]he preservation of underwater cultural heritage in situ should be considered as a first option" (Article 1). Therefore, it continued, "[n]on-destructive techniques, nonintrusive survey and sampling should be encouraged in preference to excavation" and "[i]nvestigation must not adversely impact the underwater cultural heritage more than is necessary for the mitigatory or research objectives of the project." This was particularly obvious, the article concluded, when it comes to "avoid[ing] unnecessary disturbance of human remains or venerated sites." Article 5 of the Sofia Charter likewise recalls that " $[\mathrm{t}]$ he methodology should accord with the research objectives of the investigation

4 Recommendation concerning the Preservation of Cultural Property endangered by Public or Private Works, November 19, 1968.

5 Recommendation No R (93) 9 on the protection of the architectural heritage against natural disasters, November 23, 1993

6 Charter for the Protection and Management of the Archaeological Heritage, prepared by the International Committee for the Management of Archaeological Heritage (ICAHM) and approved by the 9th ICOMOS General Assembly in Lausanne in 1990.

7 Charter on the Protection and Management of Underwater Cultural Heritage, ratified by the 11th ICOMOS General Assembly in Sofia, Bulgaria, October 1996. 
and the techniques employed must be as unintrusive as possible."

This in situ preservation need not be at odds with access-even physical access- to the information the archaeological site has to offer. Article 10 of the Sofia Charter provides, "[a] programme of site management must be prepared, detailing measures for protecting and managing in situ underwater cultural heritage in the course of an[d] upon termination of fieldwork. The programme should include public information, reasonable provision for site stabilisation, monitoring and protection against interference. Public access to in situ underwater cultural heritage should be promoted, except where access is incompatible with protection and management."

Needless to say, the Sofia Charter had a significant impact on the negotiation of the 2001 UNESCO Convention, serving as the inspiration for the text of its Annex (Aznar 2004). When the Sofia Charter was adopted in 1996, a first draft of the future Convention had already been drawn up within the ILA. Indeed, it was in the context of the ILA, which had had a Committee on Cultural Heritage Law since 1988, that work began on a first draft of the convention in 1990, revised in 1992 and 1993 and sent to UNESCO in 1994, the explanatory commentary for which already affirmed that "the best way of protecting the underwater cultural heritage is to keep it in place unless its removal is necessary for scientific or protective purposes. Thus," the commentary concluded, "all efforts must be made to prevent unscientific excavations" (O’Keefe and Nafziger 1994). To this end, it planned for the creation of underwater "cultural heritage areas" (draft Article 5).

Following the adoption of the 2001 Convention, UNESCO continued its scientific-scholarly work, paying special attention to the principle of in situ preservation. Thus, after warning that all excavations have an innate destructive component, its Manual for Activities directed at Underwater Cultural Heritage recalled that "[w]hile carefully documenting and combining evidence as recognized, [excavation] also destroys the coherence and context of a site. Although excavation can make the heritage more accessible, it also compromises to a greater or lesser extent the site's authenticity, the quality that is most respected in experiencing and enjoying a place, in identifying with it, or in terms of commemoration" (Maarleveld et al. 2013, 22).

Additionally, its Training Manual for the UNESCO Foundation Course on the Protection and Management of Underwater Cultural Heritage in Asia and the Pacific devotes an entire section to in situ preservation, citing six basic arguments: (i) a representative portion of our maritime past has to be preserved for future enjoyment and research; (ii) today, most countries have an adequate law and regulation system concerning maritime archaeological heritage; (iii) the number of shipwrecks discovered is growing fast and there is not enough capacity to do the necessary research; (iv) excavating underwater cultural heritage can be very expensive; (v) even when a site is likely to be excavated, there is generally a prolonged period of time between its discovery and the actual excavation; and (vi) an additional reason to preserve archaeological sites in situ is the current lack of knowledge on how to treat certain processes of deterioration (Manders 2012, 3-6).

All of these arguments made by the scientific community have been taken into account in the process of establishing the principle of in situ preservation not only as an archaeological rule but also a as a legal principle, which has gradually been incorporated into international law on the protection of cultural heritage, in general, and of underwater cultural heritage, in particular. The extensive scientific output since the 1980s has played a significant role in this regard. This literature takes in situ preservation for granted and examines in detail the technical complexities, scientific procedures followed, and material and human resources used to prevent the decontextualization of the investigated cultural heritage (Corzo and Hodges 1987; ICOMOS 1996; Nixon 2004; Lillie and Smith 2009). All of this bears witness to the principle's establishment in the field of archaeology, despite occasional criticism (Caple 2008). 


\section{The in situ principle as an international legal rule}

In addition to being confirmed as an archaeological principle at the scientific level, in situ preservation was also incorporated into various domestic and international legal texts over the course of the $20^{\text {th }}$ century (Williams 1978; O'Keefe and Prott 1984). This was particularly true in relation to underwater cultural heritage (Varmer 1999; Migliorino 1995).

\subsection{The general confirmation of the rule in international cultural heritage law}

In the international arena, the principle of in situ preservation is a logical outgrowth of the precautionary principle, widely applied in the field of international environmental law and contained in myriad agreements and declarations (see, in particular, Principle 15 of the Río Declaration on Environment and Development), ${ }^{8}$ as well as in international case law (Corti Varela, 2017).

In the field of international cultural heritage law, it was included in the agreements concerning the protection of world cultural heritage in both peacetime and situations of armed conflict. In the case of the former, the very nature of the cultural heritage protected by the 1972 UNESCO Convention concerning the Protection of the World Cultural and Natural Heritage - essentially property (monuments, groups of buildings, and sites) - means that it must be protected in its original location. Similarly, the raison d'être for both the 1970 UNESCO Convention on the Means of Prohibiting and Preventing the Illicit Import, Export and Transfer of Ownership of Cultural Property (1970 Convention) ${ }^{10}$ and the 1995 UNIDROIT Convention on Stolen or Illegally Exported Cultural Objects (UNIDROIT Convention) ${ }^{11}$ was the return of cultural goods to their places of origin insofar as they consider that "cultural property constitutes one of the basic elements of civilization and national culture, and that its true value can be appreciated only in relation to the fullest possible information regarding is origin, history and traditional setting" (Preamble, 1970 Convention) and that its decontextualization results in the "loss of irreplaceable archaeological, historical and scientific information" (Preamble, UNIDROIT Convention).

However, it has been at the regional level (in particular, in Europe and the Mediterranean) where the principle of in situ preservation has been expressly incorporated into the law. Article 4 of the 1992 European Convention on the Protection of the Archaeological Heritage (Revised) (Valetta Convention) ${ }^{12}$ provides that each State party "undertakes to implement measures for the physical protection of the archaeological heritage, making provision, as circumstances demand: [...] (ii) for the conservation and maintenance of the archaeological heritage, preferably in situ." The same article likewise provides that each State party undertakes to implement measures for "the acquisition or protection by other appropriate means by the authorities of areas intended to constitute archaeological reserves." Article 5 further calls upon them "to make provision, when elements of the archaeological heritage have been found during development work, for their conservation in situ when feasible." In the sphere of the Mediterranean in particular, and of the Convention for the Protection of the Marine Environment and the Coastal Region of the Mediterranean, ${ }^{13}$ Article 13(2) of the 2008 Protocol on Integrated Coastal Zone

8 Río Declaration on Environment and Development (UN Doc. A/CONF.151/26 (Vol.1), August 12, 1992.

9 UNESCO Convention concerning the Protection of the World Cultural and Natural Heritage, adopted November 16, 1972, entered into force December 17, 1975. 1037 UNTS 151.

10 UNESCO Convention on the Means of Prohibiting and Preventing the Illicit Import, Export and Transfer of Ownership of Cultural Property, adopted November 14, 1970, entered into force April 24, 1972, 823 UNTS 231.

11 UNDROIT Convention on stolen or illegally exported cultural objects, adopted June 24, 1995, entered into force July 1, 1998, 2421 UNTS 457.

12 European Convention on the Protection of the Archaeological Heritage (Revised), adopted January 16, 1992, entered into force on July 25, 1995, CETS No. 143.

13 Convention for the Protection of the Marine Environment and the Coastal Region of the Mediterranean, adopted June 10, 1995, entered into force July 9, 2004. This Convention replaces the previous Convention for the Protection of the Mediterranean against Pollution (adopted February 16, 1976, entered into force February 12, 1978). 
Management ${ }^{14}$ provides that the States parties "shall ensure that the preservation in situ of the cultural heritage of coastal zones is considered as the first option before any intervention directed at this heritage."

As for cases of armed conflict, in light of the various conflicts that have taken place since its adoption, the Convention for the Protection of Cultural Property in the Event of Armed Conflict ${ }^{15}$ was improved through the adoption of a Second Protocol, on 29 March 1999.16 The treatment of the safeguard measures so succinctly provided for in Article 3 of the original 1954 Convention is significant. Specifically, Article 5 of the 1999 Protocol provides,

\footnotetext{
"Preparatory measures taken in time of peace for the safeguarding of cultural property against the foreseeable effects of an armed conflict pursuant to Article 3 of the Convention shall include, as appropriate, the preparation of inventories, the planning of emergency measures for protection against fire or structural collapse, the preparation for the removal of movable cultural property or the provision for adequate in situ protection of such property, and the designation of competent authorities responsible for the safeguarding of cultural property."
}

The principle of in situ preservation is thus accepted as a general criterion in multiple international agreements concerning the protection of cultural heritage in general and, especially, in Europe. In contrast, the 1976 Convention on the Protection of the Archaeological, Historical, and Artistic Heritage of the American Nations ${ }^{17}$ makes no mention of the in situ rule.

\subsection{The confirmation of the rule with regard to underwater cultural heritage}

The legal protection of underwater cultural heritage reflects two regulatory logics: ratione materiæ, it is protected by international cultural heritage law; ratione loci, international law of the sea applies. These two logics, which are sometimes dialectically opposed (Cassan 2003), have shaped the current protection system, largely subordinating cultural law to the law of the sea. It should be recalled that, in accordance with Article 3 of the 2001 UNESCO Convention, nothing in the Convention "shall prejudice the rights, jurisdiction and duties of States under international law, including the United Nations Convention on the Law of the Sea. This Convention shall be interpreted and applied in the context of and in a manner consistent with international law, including the United Nations Convention on the Law of the Sea." The content and scope of this precept was the source of great debate during the Convention's negotiation, even prompting some States to abstain or vote "no" in the final vote (Aznar 2004, 296-306).

As is well known, current law of the sea has generally been codified in the UN Convention on the Law of the Sea (LOSC). ${ }^{18}$ The regulation of underwater cultural heritage in the LOSC, which has been referred to as a "Constitution for the Oceans," is both superficial and contradictory (Aznar 2016). Only two articles of the extensive text, Articles 149 and 303, refer to underwater cultural heritage, and they do so in ways only implicitly related to the principle of in situ preservation. Article 149, which concerns only the "archaeological and historical objects" located in the Area (i.e., "the seabed and the ocean floor and subsoil thereof, beyond the limits of national jurisdiction," Art. 1(1)(1) LOSC), provides that they "shall be preserved or disposed of for the benefit of mankind as a whole, particular regard being paid to the preferential rights of the State or country of origin, or the State of cultural origin, or the State of historical and archaeological origin." Some have argued that the term "preserved" is an implicit reference

14 Protocol on Integrated Coastal Zone Management, adopted January 21, 2008, entered into force March 24, 2011, EU OJ L 34.

15 Convention for the Protection of Cultural Property in the Event of Armed Conflict, adopted May 14, 1954, entered into force August 7, 1956, 249 UNTS 215.

16 Second Protocol to the Convention for the Protection of Cultural Property in the Event of Armed Conflict, adopted May 14, 1954, entered into force March 9, 2004, 2253 UNTS 172.

17 Convention on the Protection of the Archaeological, Historical, and Artistic Heritage of the American Nations, approved by the OAS General Assembly on June 16, 1976, through Resolution AG/RES. 210 (VI-O/76).

18 UN Convention on the Law of the Sea, adopted December 10, 1982, entered into force November 16, 1994) 1833 UNTS 397. 
to in situ preservation, although such an interpretation is soon belied by the subsequent reference to the possibility of "disposing" of these objects (Migliorino 1995, 486-487).

Meanwhile, it is impossible to infer, by any stretch of the imagination, an obligation to protect in situ the "archaeological and historical objects found at sea" to which the provisions of Article 303 refer. Although paragraph 1 recalls that "States have the duty to protect objects of an archaeological and historical nature found at sea and shall cooperate for this purpose," paragraph 3 contradicts the possible in situ preservation of such objects the moment it accepts that the generic obligation contained in the first paragraph does not affect "the rights of identifiable owners, the law of salvage or other rules of admiralty, or laws and practices with respect to cultural exchanges." However, paragraph 4 warns that Article 303 should be understood "without prejudice to other international agreements and rules of international law regarding the protection of objects of an archaeological and historical nature." Initially intended to safeguard the application of such agreements already in existence when the LOSC was negotiated-in particular, the Agreement between the Netherlands and Australia Concerning Old Dutch Shipwrecks ${ }^{19}$ paragraph 4 also enables the regulation of the protection of underwater cultural heritage by other agreements subsequent to the 1982 Convention. The 2001 UNESCO Convention falls into this latter category. In a certain sense it is both a development of the LOSC and subject to it, and its articles make express reference to the principle of in situ preservation.

Indeed, Article 2(5) of the 2001 UNESCO Convention elevates in situ preservation to the status of principle, providing that " $\mathrm{t}]$ he preservation in situ of underwater cultural heritage shall be considered as the first option before allowing or engaging in any activities directed at this heritage." This general principle of the Convention is further developed in Rule 1 of the Annex, which provides as follows:

\footnotetext{
"The protection of underwater cultural heritage through in situ preservation shall be considered as the first option. Accordingly, activities directed at underwater cultural heritage shall be authorized in a manner consistent with the protection of that heritage, and subject to that requirement may be authorized for the purpose of making a significant contribution to protection or knowledge or enhancement of underwater cultural heritage."
}

The annexed Rules-which, in accordance with Article 33 of the Convention, form an integral part thereof and, therefore, have the same binding force as the main text of the Convention-are based on the Sofia Charter adopted by ICOMOS in 1996. Accordingly, they develop the principle of in situ preservation of underwater cultural heritage as a first option similarly-and with similar importance. Thus, activities directed at such heritage "shall not adversely affect the underwater cultural heritage more than is necessary for the objectives of the project" (Rule 3). This precaution is even stronger when there are human remains in the sunken wreck, which, according to Article 2(9) of the Convention, must be given proper respect. Rule 5 significantly expands upon that article, indicating that "[a]ctivities directed at underwater cultural heritage shall avoid the unnecessary disturbance of human remains or venerated sites." The latter is important because, due to the underwater conditions, there may no longer be any physical human remains left in, say, a maritime war grave, which, notwithstanding, would be an example of a "venerated site" (Pérez-Álvaro 2014; Forrest 2015; Aznar 2015). The activities "must use nondestructive techniques and survey methods in preference to recovery of objects. If excavation or recovery is necessary for the purpose of scientific studies or for the ultimate protection of the underwater cultural heritage, the methods and techniques used must be as non-destructive as possible and contribute to the preservation of the remains" (Rule 4). Considering that, furthermore, the "survey, excavation and protection of underwater cultural heritage necessitate the availability and application of special scientific methods and the use of suitable techniques and equipment as well as a high degree of professional specialization, all of which indicate a need for uniform governing criteria" (Preamble of the Convention), the first option should be understood to be a preference for acting scientifically with regard to heritage in

19 Agreement between the Netherlands and Australia concerning old Dutch shipwrecks, November 6, 1972, text in Australian Treaty Series No. 18 (1972). 
its original location, respecting its natural context (Article 1 and Rule 14). Only in those cases in which its removal is deemed scientifically advisable would in situ preservation cease to be the first option. As can be seen, "[t]he consideration given to preservation in situ by the Convention and its ANNEX is based on the recognition of the importance of the interplay between the site, its story and its context" (Maarleveld et al. 2013, 20).

There seems to be a terminological discrepancy between the authentic versions of the text of the Convention and Annex in Spanish and French, on the one hand, and in English on the other. While the first two versions speak of an opción prioritaria/ option prioritaire (literally, "priority option"), the English text uses the term "first option." As established by the general rule for interpreting treaties authenticated in two or more languages, codified in Article 33, paragraphs 3 and 4, of the 1969 Vienna Convention on the Law of Treaties, "[t]he terms of a treaty are presumed to have the same meaning in each authentic text." Furthermore, in the event of a discrepancy in meaning (which is not considered to be the case here), "the meaning which best reconciles the texts, having regard to the object and purpose of the treaty, shall be adopted." Interpreted contextually (the compulsory general method of interpretation codified by Article 31, paragraph 1 of the Vienna Convention), the Annex to the UNESCO Convention contains archaeological action protocols that give meaning to the concept of "in situ preservation as the first option" or "opción prioritaria/option prioritaire." This meaning consists simply in understanding: first, that "activities directed at underwater cultural heritage shall be authorized in a manner consistent with the protection of that heritage" and, subject to that requirement, "may be authorized for the purpose of making a significant contribution to protection or knowledge or enhancement of underwater cultural heritage" (Rule 1); second, that those activities "shall not adversely affect the underwater cultural heritage more than is necessary for the objectives of the project" (Rule 3); third, that they "must use nondestructive techniques and survey methods in preference to recovery of objects" (Rule 4); and fourth, "[i]f excavation or recovery is necessary for the purpose of scientific studies or for the ultimate protection of the underwater cultural heritage, the methods and techniques used must be as non-destructive as possible and contribute to the preservation of the remains" (Rule 4). Finally, activities directed at underwater cultural heritage "shall avoid the unnecessary disturbance of human remains or venerated sites" (Rule 5). Considering, also, that the "survey, excavation and protection of underwater cultural heritage necessitate the availability and application of special scientific methods and the use of suitable techniques and equipment as well as a high degree of professional specialization, all of which indicate a need for uniform governing criteria" (Preamble to the Convention), it should be understood that, as a first option/opción prioritaria/option prioritaire, preference must be given to acting scientifically on the heritage in the place where it is found, respecting its natural context (Article 1 and Rule 14). Only in cases in which removal is considered appropriate from a scientific perspective (to enable better study or due to danger at the site) would in situ preservation cease to be the "first" or "priority" option.

In short, the 2001 UNESCO Convention enshrines in situ preservation as a "first option" as a legal principle. However, in keeping with the content of the archaeological principle, it is nevertheless still only an option. Thus, while it may be the first to be weighed, it can also be ruled out if-following the requisite technical assessments and scientific analyses of the context-the conditions of the site (in terms of the risks or hazards involved) or the need to enable better study, conservation or enhancement of the objects make it preferable to remove them and conserve them or display/musealize them somewhere other than where they were found underwater. As has been noted elsewhere, "the principle of in situ preservation does not therefore mean that underwater cultural heritage is never recovered, only that it is recovered for a sound reason, and only after pre-disturbance archaeological investigation has been undertaken" (Forrest 2010, 341-342).

It should be stressed that the text of the Convention uses the term "first option," not "preferred option." That is not due to another of the text's constructive ambiguities, but rather was deliberately chosen by the drafters, who sought to prevent misunderstandings: as we have seen, in situ preservation 
was to be simply another option in the course of a site's management, perhaps the first, but by no means the only one. As has been argued, "[i]n each individual case, preservation in situ may be the preferred option; however, it depends on the precise circumstances. It is certainly not the only option and it is not the inevitable outcome of the application of the Convention" (Dromgoole 2013, 314). Indeed, the preparatory work for the Convention (which can be used as supplementary means for its interpretation in accordance with the general rules of international law on the interpretation of treaties as codified in Article 32 of the Vienna Convention) shows that there was some debate on the matter. In fact, unlike the other Rules, it was not possible to adopt Rule 1 (on the principle of in situ preservation itself) and Rule 7 (on responsible in situ access) by consensus, although they were ultimately adopted by a very broad majority of the negotiating States (Garabello 2003, 115-117).

Subsequent practice has likewise been consistent. Some agreements concerning underwater cultural heritage concluded after the adoption of the 2001 UNESCO Convention go into great detail regarding the idea that it should preferentially be protected at its place of origin. The most important, due to its turbulent past, is the agreement concluded between Canada, the United States, France, and the United Kingdom to preserve the wreck of the Titanic (the Titanic Agreement) ${ }^{20}$ (Aznar and Varmer 2013). This Agreement makes express mention of the principle, recognizing in the Preamble that "in situ preservation is the most effective way to ensure such protection, unless otherwise justified by educational, scientific or cultural interests, including the need to protect the integrity of RMS Titanic and/or its artifacts from a significant threat." Additionally, Article 4(2) provides that

\footnotetext{
"[e]ach Party agrees that the preferred management technique is in situ preservation and that project authorizations referred to in this Article involving recovery or excavation aimed at RMS Titanic and/or its artifacts should be granted only when justified by educational, scientific, or cultural interests, including the need to protect the integrity of RMS Titanic and/or its artifacts from a significant threat."
}

The Annex to the Titanic Agreement, which contains the "Rules concerning activities aimed at the RMS Titanic and/or its artifacts" (inspired by the Rules annexed to the 2001 UNESCO Convention), reaffirms as one of its general principles that "[t]he preferred policy for the preservation of RMS Titanic and its artifacts is in situ preservation." Here, reference should be made to the NOAA Guidelines for Research, Exploration and Salvage of RMS Titanic, ${ }^{21}$ especially Commentary 11, which informed the Agreement.

The application of the exceptions to the principle, in particular the need for better scientific understanding, is exemplified by the Agreement between France and the United States regarding the wreck of La Belle, ${ }^{22}$ an auxiliary vessel of the French Navy that, under the command of Robert Cavalier, Sieur de la Salle, sank in 1686 in what is now Matagorda Bay, Texas. As a result of that agreement, today, its completely excavated remains are under the custody of the Texas Historical Commission..$^{23}$ Exceptions are also present in the final decision to excavate and note preserve in situ the remains of the Mazarrón II wreck, a probably Phoenician vessel found in the south-east coast of Spain (Aznar 2017).

It is thus (primarily) international legal texts that, today, include in situ preservation as a principle. Although domestic legal systems also include it in some cases, it is generally only implicitly, requiring the preservation of the remains in the place where they are found (usually through the creation of protected areas or sanctuaries) and allowing them to be excavated only after the necessary permits have been obtained. Examples of this can be found in Australian, ${ }^{24}$ British, ${ }^{25}$ Chinese, ${ }^{26}$ French, ${ }^{27}$ Greek, ${ }^{28}$ Italian, ${ }^{29}$

20 Agreement Concerning the Shipwrecked Vessel RMS Titanic, adopted November 6, 2003, not yet in force.

21 NOAA Guidelines for Research, Exploration and Salvage of RMS Titanic [66 Fed.Reg 18906 (April 12, 2001)].

22 Agreement signed by the U.S. and France regarding custody of the sunken French vessel La Belle, March 31, 2003, in force March 31, 2003.

23 The excavation was decided given the peculiar circumstances of the wreck and, logically, with the agreement of the sovereign of the remains (i.e., France), as it was a non-abandoned sunken state vessel. See, in addition to the Agreement, the Administrative Arrangement, Texas Historical Commission - Musée National de la Marine, March 31, 2003 (author's files).

24 Historic Shipwrecks Act 1976. 
Portuguese, ${ }^{30}$ South African, ${ }^{31}$ and US law. ${ }^{32}$ It is likewise the case with Spanish domestic law (Aznar 2017).

\section{Concluding remarks}

The principle of in situ preservation will surely continue to spark debate, not so much over its existence, which this paper has demonstrated at both the archaeological and legal level, as over the exact conditions of its application.

Following its incorporation as a basic tenet of archaeology, especially with regard to underwater archaeology, the principle was legally enshrined at the international level after a fruitful collaboration between historians, archaeologists, curators, politicians, diplomats, and jurists. This collaboration was based on scientific debate and continuous dialogue between the archaeological and legal spheres. The presence of experts at the international negotiations, clearly reflected in the conventional efforts of the CoE and UNESCO, began to bear significant fruit in the 1990s, especially with the inclusion of the Annex in the 2001 UNESCO Convention.

Indeed, from that moment on, the principle of in situ preservation of underwater cultural heritage as the first option, except in situations of risk or need for better scientific understanding or enhancement, has been internationally binding on the States parties of the 1992 Valetta Convention and the 2001 UNESCO Convention, among others. It is only a matter of time and State practice before the conventional nature of the principle generates a similar obligation at the customary level. This paper has shown how some of the States most interested in underwater cultural heritage have, in one way or another, already incorporated the principle of in situ preservation into their domestic law.

\section{References}

Aznar, M.J. (2004), La protección del patrimonio cultural subacuático. Especial referencia al caso de España. Valencia: Tirant.

Aznar, M.J. and Varmer, O. (2013), The Titanic as Underwater Cultural Heritage: Challenges to its Legal International Protection. Ocean Development \& International Law, doi: 10.1080/00908320.2013.750978.

Aznar, M.J. (2015), Regarding 'Les epaves de navires en haute mer et le droit international. Le cas du Mont-Louis' by Guido Starkle (1084/1985-I): 'Sensitive' wrecks, protecting them and protecting from them, Revue Belge de Droit International, 74-88.

Aznar, M.J. (2016), The legal protection of underwater cultural heritage: concerns and proposals. In Crawford et al., The International Legal Order: Current Needs and Possible Responses, doi: 10.1163/9789004314375_019.

Aznar, M.J. (2017), Aspectos jurídicos de la protección in situ del patrimonio cultural subacuático. In M. Martínez Alcalde, J.M. García Cano, J. Blánquez Pérez \& Á. Iniesta Sanmartín (eds), Mazarrón II. Contexto arqueológico, viabilidad científica y perspectiva patrimonial del barco B-2 de la bahía de Mazarrón (Murcia). En homenaje a Julio Mas García (pp. 123-161). Madrid: UAM Ediciones.

Burnouf, J. et al. (2012), Manuel d’archéologie médiévale et moderne, Paris: Armand Colin.

Caple, C. (2008), Preservation In Situ: The Future for Archaeological Conservators? Studies in Conservation, doi: 10.1179/sic.2008.53.Supplement-1.214.

25 Protection of Wrecks Act 1973 and Protection of Military Remains Act 1986.

26 Protection of Cultural Relics Law (1982) and the Regulations on Protection and Administration of Underwater Cultural Relics (1989).

27 Code du Patrimoine, Chap. 2, Title III, Book V and its reglamentary rule in Art. R532.

28 Law 3028/2002, on the Protection of Antiquities and Cultural Heritage in general.

29 Decreto Legislativo 22 gennaio 2004, n. 42, "Codice dei beni culturali e del paesaggio, ai sensi dell'articolo 10 della legge 6 luglio 2002, n. 137” (Gazzetta Ufficiale n. 45 del 24 febbraio 2004 - Supplemento Ordinario n. 28).

30 Decreto-Lei no 164/97, June 27, 1997 (Diário da República - I Série-A № 146 - June 27, 1997).

31 National Monuments Amendment Act 1979.

32 National Marine Sanctuaries Act (16 U.S.C. s. 1431). 
Carman, J., Cooper, M., Firth, A. and Wheatley, D. (eds.), (1995), Managing Archaeology, London: Routledge.

Cassan, H. (2003), Le patrimoine culturel subaquatique ou la dialectique de l'objet et du lieu. In Anderson, DH, Bastid-Burdeau, G., Bedjaoui, M. and Beer-Gabel, J (Eds.), La mer et son droit. Mélanges offerts à Laurent Lucchini et Jean-Pierre Quéneudec (pp. 127-148). Paris: Pedone.

Cleere, H. (Ed) (1984), Approaches to the Archaeological Heritage, Cambridge: CUP.

Corti Varela, J. (2017), El principio de precaución en la jurisprudencia internacional, Revista Española de Derecho Internacional, 69, 219-243.

Corzo, M.A. and Hodges, H.H. (1987), In situ archaeological conservation (Proceedings of meetings April 6-13, 1986). México and Los Angeles (Cal.): Getty Conservation Institute.

Delgado, J.P. (Ed) (1997), Encyclopædia of Underwater and Maritime Archaeology. London: British Museum Press.

Dromgoole, S. (2013), Underwater Cultural Heritage and International Law, Cambridge: CUP.

Forrest, C. (2010), International Law and the Protection of Cultural Heritage, London: Routledge.

Forrest, C. (2015), Towards the Recognition of Maritime War Graves in International Law. In Underwater Cultural Heritage from World War I (Proceedings of the Scientific Conference on the Occasion of the Centenary of WWI, Bruges, June 26 \& 27, 2014) (pp. 126-34). Paris: UNESCO. http://www.unesco.org/culture/underwater/world-warI.pdf. Accessed November 30, 2017.

Khakzad, S. and Van Balen, K. (2012), Complications and Effectiveness of In Situ Preservation Methods for Underwater Cultural Heritage Sites, Conservation and Management of Archaeological Sites, 14(1-4), 469-478.

Garabello, R. (2003), The Negotiating History of the Convention on the Protection of the Underwater Cultural Heritage. In Garabello, R. \& Scovazzi, T. (Eds) (2003), The Protection of the Underwater Cultural Heritage, before and after the 2001 UNESCO Convention (pp. 89-192). Leiden/Boston: Brill.

Gianfrotta, P.A. and Pomey, P. (1981), Archeologia subacquea: storia, tecniche, scoperte e relitti, Milano: Mondadori.

Grenier, R., Nutley, D. and Cochran, I. (Eds) (2006), Underwater Cultural Heritage at Risk: Managing Natural and Human Impacts. Paris: ICOMOS. http://www.icomos.org/risk/2006/fulldocan.pdf. Accessed 30 November 2017.

Hodges, H.W. (1993), In Situ Archaeological Conservation, Oxford: OUP.

ICOMOS (1996), Archaeological Remais, In Situ Preservation (Proceedings of the Second ICAHM International COnference, Montréal (Quebec) Canada, October 11-15, 1994. http://ip51.icomos.org/ fleblanc/publications/pub_icomos/pub_1994_icomoscanada_archaeological_remains_pages_000-154.pdf. Accessed 30 November 2017.

Langley, S.B.M. and Unger, R.G. (Eds) (1984), Nautical archaeology, progress and public responsibility, Oxford: British Archaeological Reports International Series 220.

Lillie, M. and Smith, R., 2009, International literature review: in situ preservation of organic archaeological remains, Hull (UK): University of Hull.

Maarleveld, T., Guerin, U. and Egger, B. (Eds) (2013), Manual for Activities Directed at Underwater Cultural Heritage. Paris. UNESCO. http://www.unesco.org/culture/en/underwater/pdf/UCH-Manual.pdf. Accessed November 30, 2017.

Manders, M.R. (2012), Unit 9: In Situ Preservation. In UNESCO Training Manual for activities directed at Underwater Cultural Heritage. Paris: UNESCO. http://unesdoc.unesco.org/images/0021/002172/217234e.pdf. Accessed November 30, 2017.

Martín Bueno, M. (2003), Patrimonio Cultural Sumergido: Investigar y conservar para el futuro, Monte Buciero, 9, 21-62.

Migliorino, L. (1995), In situ protection of the underwater cultural heritage under international treaties and national legislations, The International Journal of Marine and Coastal Law, doi: 10.1163/157180895X00240.

Nixon, T., (Ed) (2004), Preserving Archaeological Remains in Situ? (Proceedings of the 2nd Conference 12-14 September 2001). London: Museum of London Archaeology Service.

O’Keefe, P.J. and Prott, L. (1984), Law and the Cultural Heritage. Oxford: OUP.

O'Keefe, P.J. and Nafziger, J. (1994), Report: The Draft Convention on the Protection of the Underwater Cultural Heritage. Ocean Development and International Law, doi: 10.1080/00908329409546041.

O’Keefe, P., Péron, C., Musayev, T. y Ferrari, G. (2016), Protection of Cultural Property, Military Manual. Paris: UNESCO. http://openarchive.icomos.org/1739/1/Protecting\%20Cultural\%20Property\%20Military\%20Manual\%20UNESCO\%20Blue\%20Sh ield\%20246633e.pdf. Accessed November 30, 2017. 
Pérez-Álvaro, E. (2014), The management of human remains on shipwrecks: ethical attitudes and legal approaches. In Tilburg, H.V. et al. (Eds), Second Asia-Pacific Regional Conference on Underwater Cultural Heritage. Honolulu, Electric Pencil. http://www.themua.org/collections/files/original/c0de69a424343e4f586b8883679bb3e3.pdf. Accessed November 30, 2017.

Rahtz, P.A. (Ed) (1974), Rescue archaeology. London: Pelican Books.

Sease, C. (1996), A short history of archaeological conservation. Studies in Conservation, doi: 10.1179/sic.1996.41.Supplement1.157 .

Smith, C. (ed.) (2014), Encyclopedia of Global Archaeology. Nueva York: Springer.

Thomas, D.H. (1989), Archaeology. Fort Worth: Holt, Rinehart and Wynson.

Trotzig, G. and Vahlne, G. (Eds) (1989), Archaeology and Society. Stockholm: Nordic Secretariat of ICAHM.

Varmer, O. (1999), The Case Against the 'Salvage' of the Cultural Heritage. Journal of Maritime Law and Commerce. http://www.gc.noaa.gov/documents/2012/04-1999-varmer-salvage.pdf. Accessed November 30, 2017.

Vlad Borrelli, L. (1995), Conservazione. In Vedovato, G. and Vlad Borrelli, L. (Dir) (1993), La tutela del patrimonio archeolohgico subacqueo (Atti del convegno tenutori a Ravello dal 27 al 20 maggio 1993) (pp. 69-79). Rome: Istituto poligrafico e Zecca dello Stato, Libreria dello Stato.

Williams, S.A. (1978), The International and National Protection of Movable Cultural Property: A Comparative Study. New York: Oceana Publications. 